\title{
PROFESSIONAL COMPETENCE DEVELOPMENT: A PHENOMENOLOGICAL STUDY OF EFL TEACHERS AT SMA NEGERI 1 PAREPARE
}

\author{
Arqam \\ LAIN Parepare \\ arqam@stainparepare.ac.id
}

\begin{abstract}
Teacher's professional competence development becomes very important in the general area of study of education, it is probably because the professional competence development of the teacher plays an important role in their performance in teaching and the interaction with the students and other members of the school community. So, the problem statement of this research are: (i) What are the EFL teacher's at SMA Negeri 1 Parepare Perspectives on the meaning of professional competence development. The research applying a qualitative descriptive method in the form of a phenomenological study approach. The findings indicate that (i) EFL teacher's perspectives on the meaning of professional competence development in SMA Negeri 1 Parepare are: English teacher's professional competence development is very necessary and very helpful it feels like a re-fresh and recharge program, English teacher's professional competence development is very influential in increasing them selfconfidence at teaching and influential to the teaching quality for both professional and pedagogical competence, Professional competence development very much helped to improve their professional and pedagogical competence, EFL teacher's professional competence development has very good and a lot of positive effects for their profession as a teacher, EFL teacher's professional competence development is really feel indeed greatly help improve their quality in teaching.
\end{abstract}

Keywords: Professional competence, EFL Teachers, phenomenological study, pedagogical competence

\section{A. INTRODUCTION}

$\mathrm{I}$

$\mathrm{n}$ Indonesia, the duties of teachers are established in the act on the National Sistem of education No. 14/2005, especially chapter III article 7 paragraph 1 . It is stated that one of the responsibilities of teachers or educational workers is "to have professional commitment to improve quality of education. (Undang-undang Republik Indonesia, No 14 Tahun 2005, p.3)

Teacher's professional competence development becomes very important in general area or study of education, it is probably because the professional competence development of the teacher plays an important role in their performance in teaching and the interaction with the students and other members of the school community. The teacher's professional competence is a set of capabilities that must be owned by a teacher 
broadly and deeply so that he can carry out his teaching duties successfully, such as; able to master his skills, able to influence the students' learning process and able to manage a conducive classroom, so that students have the ability to learn. The competencies required of a teacher, consisting of four, namely; professional competence, pedagogic competence, personal competence, and social competence. Development in the field of education is a good media to create human resources.

As a foreign language, English would be difficult to teach or learn. Therefore, it takes more skills to be able to teach it because besides teaching materials, curriculum and methods, the teacher's competence is necessary for the successful process of teaching and learning that lead to increased the students' interest of the material. Thus we can conclude that the teaching materials in order to be accepted by students, the performance of the teachers must first be accepted by students in terms of scientific, social, pedagogy and professionalism. This problem that often becomes the biggest obstacle that greatly affect the student's success because although the students have high interest, but if it is not matched with adequate competence of the teacher's communication will not be established by either in the classroom, and therefore the synergy between teachers and students are needed for smooth learning process to achieve the educational goals as expected.

All English language teachers must have opportunities to update their knowledge and practices to grow in the language. Opportunities for English language teacher's professional competence development must expand the teacher's language and teaching skills from entry level to increasingly higher levels of proficiency. Because more proficient teachers are usually more effective teachers. The teacher's professionalism and competence are two of the affecting factors for the successful in teaching English as the mandatory subject in Indonesian school. Because of the important role of that teachers have, EFL teachers need to be able to improve and develop their professional competences. As may be not easy to say what professional competence English language teachers should possess or how they should improve and develop as professionals. This is because the concept of ELF teacher's professional competence itself is relatively not easy to define and it is constantly changing. Also, the aim of the study is to investigate English teacher's professional competence development within the Indonesian 
educational context a context which is characterised with a lot of complex realities, limitations and obstacles in its classroom. Perhaps for Indonesian context, English teachers following Walker's (2001) (a cited in Yuwono) brief summary are considered to be professional' if they at least: (1) have educational qualifications, (2) have good subjectmatter knowledge, and (3) are skilled practitioners in the classroom Yuwono, G. I. 2010, p.148).

This is a research, then which illustrates well researchers' contributions and observation about the teachers professional competence development which are possessed by the EFL teachers at SMA Negeri 1 Parepare, it is important to conduct a research which observed the teacher's perspectives on the meaning of professional competence development, the way of them in developing their professional competence, Above all, by this phenomena the researcher conducted a research entitled; "Professional Competence Development: A Phenomenological Study of EFL Teachers at SMA Negeri 1 Parepare".

\section{B. REVIEW OF THE LITERATURE}

Professional competence which deals with the technical knowledge of the effective English language teachers. Technical knowledge closely related to the teacher ability in mastering the English itself. How far they master English in order to teach the students the proper way of using English.

The professional development of EFL teachers represents a challenge for teachers, teacher educators and policy makers in the accomplishment of better standards in education (Moncada, A. G. 2007: 309).

There are two concepts connecting each other when we are discussing about effective language teachers, they are procedural knowledge and declarative knowledge. Nunan in Wichadee (2008: 2), states that to be effective, language teachers need these two kinds of knowledge equally mentioned above, namely:

a. Declarative Knowledge

Declarative knowledge includes all of the things teachers know and can articulate. It's knowledge about something, for example, about grammar rules. On the other hand, 
b. Procedural Knowledge

Procedural knowledge includes the ability to do things or knowing how to do things, such as being able to carry on conversations in English, knowing how to plan lessons and knowing how to conduct pair work.

According to Brown and Rodgers in Wichadee (2008: 2), to be a good teacher in an EFL class requires a combination of two components, such as:

a. A Mechanical Component

The mechanical component of a lesson includes the skills required for the content of the lesson to be presented in the most accessible ways for students

b. A Mental Component

The mental component encompasses the teacher's belief system about teaching and learning as well as the teacher's personality.

According to Richards the language-specific competencies that a language teacher needs in order to teach effectively. These include the ability to do the following kinds of things:

a. To comprehend texts accurately

b. To provide good language models

c. To maintain use of the target language in the classroom

d. To maintain fluent use of the target

e. To give explanations and instructions in the target language

f. To provide examples of words and grammatical structures and give accurate explanations (e.g., of vocabulary and language points)

g. To use appropriate classroom language

h. To select target-language resources (e.g., newspapers, magazines, the Internet)

i. To monitor his or her own speech and writing for accuracy

j. To give correct feedback on learner language

k. To provide input at an appropriate level of difficulty

1. To provide language-enrichment experiences for learners (Richards. J. C. 2011: 3)

The teacher's professional competence is a set of capabilities that must be owned by a teacher so that he can carry out his teaching duties successfully. The competencies 
required of a teacher, consisting of three, namely personal competence, social competence, and professional competence. The success of teachers in their profession is largely determined by three with an emphasis on teaching skills. Next, will be described in each discussion about the competencies that must be owned by a teacher, as follows:

a. Pedagogy Competence

These competencies include understanding the teacher to the students that there is a reference in the development of students to actualize various potentials. This competence also includes the capability of teachers in the design and implementation of learning and evaluation of learning outcomes.

\section{b. Personal Competence}

Based on human nature as individual beings and as creatures of God. He must master the knowledge to be taught to students correctly and responsibly. He must have the essential knowledge about the physiological condition, psychological, and pedagogical of the learners that it faces.

Personal competencies that should exist in a teacher, which has a deep knowledge of the subject matter which it is responsible. Additionally, having knowledge of the development of learners as well as the ability to treat them individually.

\section{c. Social Competence}

Based on human nature as social beings and being ethical. He should be able to treat their students fairly and aims to achieve optimization of the potential on each self learner. He must learn to understand and apply the principles of humanistic thought that learning success is determined by the skill that is in such learners. Instructor duty to serve their only fit their individual needs. Social competence owned by a teacher is regarding the skill to communicate with learners and their environment (such as parents, neighbors, and peers).

It can be concluded that Education is an essential activity that is undertaken to direct a person in order to achieve a goal. This process involves professional teachers in their field. Professional teacher in the field are able to master his skills, able to influence the students' learning process and able to manage a conducive classroom so that students have the ability to learn. Development in the field of education is a good media 
to create human resources. The quality of professional educator will capable to deliver the person to be a better person.

\section{RESEARCH METHOD}

This research was conducted in Parepare, a small city of South Sulawesi province Indonesia. The study itself was conducted in a State Senior High School that is known as favorite school in town. The school is SMA Negeri 1 Parepare. The subject of this research are the English teachers. Therefore, as this research is included as phenomenology study so this research aims to investigate the phenomena of the EFL teacher professional competence development for their successful teaching that existed in Parepare. Then the researcher observes the English teachers whether they represent two categories as the research subject in this research.

In collecting the data, the researcher divides the research instrument into two main categories, they are: primary instrument which consist of the researcher and tentative intevies protocol and secondary Instrument which consist of video and photo capture and recorder (Canon IXUS 160), hand phone or smart phone (Samsung Android 5 inches), field notes and every tool that may help the process of conducting this research. Particularly, it will be helpful while the researcher is doing the observation in the classroom.

There are three procedures that the researcher will apply in order to collect the systematic and valid data, they are observation, interview, and document Examination.

Generally, in qualitative research paradigm the process of data analysis using analytical flow model proposed by Miles and Huberman (1994, p.10) are often referred to as interactive data analysis methods. They revealed that the activities carried out in the analysis of qualitative data in an interactive and take place continuously until complete, so the data is already saturated. There were three concurrent flows of activities in analyzing the qualitative data, such as: data reduction, data displays, and conclusions drawing or verification. Those activities were shown in the following picture.

\section{FINDINGS}


Volume 6, Number 1, June 2020

The first research question deals with the EFL teacher's perspective on the meaning of their professional competence development after conducting the research on it the researcher emphasizes this focus on EFL teacher's responses towards the development of professional competence.

a. Ms. HRN's Perspective towards EFL Teacher's Professional Competence Development

Toward the question about what are their perspective on the meaning of English language teacher's professional competence development here is Ms HRN's response to the questions.

"For me, I can be a good teacher and give good treatment also to the students because I have been through the stages in the process of developing English teacher's professional competence that I have followed. There are many positive things that I learned and very helpful for me to do my duties at the school. The ability of our language skills automatically will be good also. One of the example is PLPG program (Teacher's Training and Development Centre) that carried out at provincial level."

"Because there are many informations that we can share in that activity, not only about the information of English teaching but also information about personel administration as civilian state apparatus for example on tax report, the target employee (SKP), PUPNS, and small meeting with use English language at the same time joking with friends."

"It is very necessary and very helpful at all, especially on program PLPG, during I follow the training of increasing teachers' competence especially English teachers, I feel like in re-fresh and frankly there are many methods and teaching strategies that I have gained and after I followed the program, it is directly applied in class because I don't want the way of my teaching method is monotony, I want there are many variations in teaching because I realize that nowadays the education has changed and it has developed rapidly and most of all the changes that accured on the learner, nowadays most of the students are mastering sophistication of technology and information such as the use of the internet or smart phone and gadget, then as a teacher I have to balance the situation and I get it through the training program such as PLPG and MGMP." Ms. HRN, Interview, Saturday August 7, 2018. FN 002) 
Based on her answer to the interview, Ms. HRN thinks that the English language teacher's professional competence development is very necessary and very helpful at all, especially on program PLPG (Teacher's Training and Development Centre), during his training program to increase the competence of teachers especially teachers of English education, it is feel like a re-fresh and recharge program. Frankly speaking she said, a lot of methods and teaching strategies that she has gained after joining the program immediately she applies in the classroom, She needs various ways of teaching, she does not want to teach monotonously, she realizes that the world of education recently develop and changing very rapidly specially to the students, most of students now following and use the sophisticated technology to facilitate their self with recently information, such as; the use of internet or a smart phone or gadget, as a teacher she must balance that situation and condition and she get one the solution through in service training programs such as PLPG, MGMP, seminar, conference and so on.

b. Mrs. SKM's Perspective towards EFL Teacher's Professional Competence Development

The next answer from Mrs. SKM shows that she also shared the same experience with Ms. HRN where she almost had the same experience about improving their teaching skills. Here is her response to the question.

"All this time I feel, the developing of English teacher professionalism competence can support my duties as a teacher, it is proved by applying what we know directly in learning process in the class, it can increase our self-confidence."

"Based on my opinion, it is very helpful, especially makes our assignments as teacher become easy and the learning process is going along smoothly even less we all as teacher make interaction, share our experiences and information in teaching at the event." "It is very influential, influential to the developing of teacher professionalism competence and it can be applied in learning process directly. It is 
also influential to the language skill mastery such as; speaking, writing, reading, and listening."

"Yes, it does. It is very influential in increasing my self-confidence at teaching."

The preceding extract shows that Mrs. SKM is really believe that the developing of English teacher professionalism competence through in service training, such as; MGMP (Teachers Field Study Meeting Club) and PLPG (Teacher Training and Development Centre), and teaching trainings or seminar by using computer application are very influential in increasing her self-confidence at teaching, and those are influential to the teaching quality for both professional and pedagogical competence, her subject-matter knowledge can be applied in learning process directly. It is also influential to her language skills mastery such as; speaking, writing, reading, and listening.

c. Mr. UMR's Perspective towards EFL Teacher's Professional Competence Development

A similar view was expressed by others teachers, such as; Mr. UMR realized that he is personally feel very much helped by these activities. The following extract is his responses to the question.

"My opinion on the EFL Teacher's professional competence development, I think, it is till very necessary to do of course with the support from various sources related to education outonomous, such as; the city education department, local government and so on. Then about EFL teachers' professional competence development that we conduct, and follow all this time, I felt very influential on the mastery of the language skills, such as; Speaking, Reading, Writing, and Listening. Moreover, as an English teacher I try to use English at least fifty percent as the instructional language when I am delivering the material to the students. Not a lot of activities that we often do in order to our disciplines, there are two commonly program and activities, namely; MGMP (Teacher's Field Study meeting Club) and PLPG (Teachers Training and Development Center) which is usually hold at the province and I am really helped, you know, language is a habit, the more we use and listen it the more we will fluent." 
"It is very necessary and very helpful at all, especially on program PLPG, during my training program to increase the competence of teachers, especially teachers of English education, it is feel like a re-fresh and recharge. Frankly speaking a lot of methods and teaching strategies that I have gained after joining the program immediately I apply in the class, I need various ways of teaching, I do not want to teach monotonous, I realize that the world of education recently develop and changing very rapidly specially to the students, most of students now following and use the sophisticated technology to facilitate their self with recently information, such as; the use of internet or a smart phone or gadget, as a teacher I must balance that situation and condition and I get one the solution of them through training programs such as PLPG and MGMPs."

What is expressed by Mr. UMR on the EFL Teacher's professional competence development, personally he feels very much helped by these activities. Mr. UMR followed several kinds of in-service training to improve his professional and pedagogical competence such as in service training for teacher quality improvement, in-service training for SSCI (Smart School System of Indonesia). He attended those trainings to improve his professional competence and his skills in teaching and also it was an appreciation from his school that delegated him to attend those trainings to improve his teaching ability.

d. Ms. FTM's Perspective towards EFL Teacher's Professional Competence Development

The next answer from Ms FTM shows that she also shared the same experience with Mr. UMR where she almost had the same experience about improving their professional and pedagogical competence. Here is her response to the questions.

"In my opinion, I am personally feel that it has effects very good and a lot for me as a teacher, for example the program and activities in MGMP which we hold every week, there, we discuss about something that relate with our profession as the English Teacher, for example; discussing about the teaching methodology, sharing the previous and latest information about strategies and teaching techniques, and the language which we use is English so automatically our speaking ability be trained too." 
"Yes,...... it is very helped to facilitate my duties as a teacher."

"Yes.... besides the knowledge about teaching methodology, understanding to design and develop the teaching scenarios increased too. And each curriculum changes we are always informed by trainings and workshops."

Ms. FTM's explanation emphasized on her English proficiency level because according to her it was the most problem she had when she was at the first year working as a teacher. She realized that she had to improve her English proficiency level to meet the students' needs in the classroom.

e. Mrs. RSD's Perspective towards EFL Teacher's Professional Competence

Development

The next answer come from Mrs. RSD. she thinks EFL teachers' professional competence development can increase teachers knowledge in generally about how to be a professional teacher. Here is her response to the questions.

"Yeah........my opinion about the development of professional competence of English teachers, I think..........this professional development such as in MGMP's activity is very positive, because in there, fellow teacher sharing each other about many things relate to our duties."

"I feel an influence on the mastery of language skills such as speaking, reading, writing and listening, especially our speaking skill, automatically be trained because we often use English as the language of instruction or a lingua franca in that activities, we also often bring reading texts for us to discuss together how to solve the test, we also plan to make a hands book just like work paper for the students and we try to be realized in this management period, but in listening comprehension subject frankly we still need technical guidance."

"Yes I think indeed greatly help improve my ability to teach as far as my experience in that teacher competence development program, we are as a teachers required to find out, it means in this case we are expected to up to date our teaching treatment, for example learning from computer like the using of Quicker school, Quicker school is the computer based program use by both teachers and students in learning via internet applications."

"Well I think yes........, For example, it can increase our knowledge about how to be a professional teacher. A lot of suitable techniques and useful information how 
to arrange, designing, and developing teaching scenario or we term here RPP that suitable and appropriate in student learning in the classroom."

What is expressed by Mrs RSD, she is really feel indeed active and participate in service training greatly help improve her ability to teach, she aware as a teacher required to find out, it means in this case teachers are expected to up to date their teaching treatment and experience, for example learning from computer like the using of Quicker school, Quicker school is the computer based program use by both teachers and students in learning via internet applications.

From those explanations about EFL teachers' perspective on the meaning of professional competence development, it can be concluded that the five research subjects have their own perspectives. It can be shown in the table 2.

Table 1. EFL Teachers' at SMA Negeri 1 Parepare Perspective on the Means of Professional Competence Development

\begin{tabular}{|c|c|c|}
\hline \multicolumn{3}{|c|}{$\begin{array}{l}\text { EFL teachers' perspectives on the means of professional competence } \\
\text { development }\end{array}$} \\
\hline No & Research Subject & Perceptions \\
\hline 1. & The $1^{\text {st }}$ Research Subject & $\begin{array}{l}\text { - The professional competence } \\
\text { development program can produce a } \\
\text { good teacher with good treatment to } \\
\text { the students } \\
\text { - Learned a lot of positive thinngs } \\
\text { - From the professional competence } \\
\text { development program } \\
\text { - The professional competence } \\
\text { development program is very helpful } \\
\text { do her job at the school. } \\
\text { - Through the professional competence }\end{array}$ \\
\hline
\end{tabular}




\begin{tabular}{|c|c|c|}
\hline & & $\begin{array}{l}\text { development program can be influence } \\
\text { significantly to improve her language } \\
\text { proficiency }\end{array}$ \\
\hline 2. & The $2^{\text {nd }}$ Research Subject & $\begin{array}{l}\text { - The professional competence } \\
\text { development program can be able to } \\
\text { support positively her duties as an } \\
\text { English teacher } \\
\text { - The knowledge from the professional } \\
\text { competence development program can } \\
\text { be applied directly in learning process } \\
\text { in the classroom } \\
\text { - The professional competence } \\
\text { development program can increase her } \\
\text { self-confidence. }\end{array}$ \\
\hline 3. & The $3^{\text {rd }}$ Research Subject & $\begin{array}{l}\text { The professional competence } \\
\text { development program he feels very } \\
\text { influential on the mastery of the } \\
\text { language skills, such as; Speaking, } \\
\text { listening, reading, and writing. } \\
\text { - Through the professional competence } \\
\text { development program he is really } \\
\text { helped to increase his spoken language }\end{array}$ \\
\hline 4. & The $4^{\text {th }}$ Research Subject & $\begin{array}{l}\text { - Through the professional competence } \\
\text { development program she is personally } \\
\text { feel that it has effects very good and a } \\
\text { lot for her as a teacher } \\
\text { - Through the professional competence }\end{array}$ \\
\hline
\end{tabular}




\begin{tabular}{|c|c|c|}
\hline & & $\begin{array}{l}\text { development program provide her to } \\
\text { discuss about something that relate } \\
\text { with her profession as the English } \\
\text { Teacher } \\
\text { - Through the professional competence } \\
\text { development program he is really } \\
\text { helped to increase his spoken language }\end{array}$ \\
\hline 5. & The $5^{\text {th }}$ Research Subject & $\begin{array}{l}\text { - The professional competence } \\
\text { development program she thinks is very } \\
\text { positive, because on that program the } \\
\text { teacher sharing each other about many } \\
\text { things relate to their jobs. } \\
\text {-, Through the professional competence } \\
\text { development program can increase her } \\
\text { knowledge about how to be a } \\
\text { professional teacher. } \\
\text { - Through the professional competence } \\
\text { development program, A lot of suitable } \\
\text { techniques and useful information she } \\
\text { gets about how to arrange, designing, } \\
\text { and developing teaching scenario. }\end{array}$ \\
\hline
\end{tabular}

\section{E. CONCLUSION}

EFL teacher's perspectives on the meaning of professional competence development in SMA Negeri 1 Parepare are:

a. English teacher's professional competence development is very necessary and very helpful it is feel like a re-fresh and recharge program 


\section{Volume 6, Number 1, June 2020}

b. English teacher's professional competence development is very influential in increasing them self-confidence at teaching and influential to the teaching quality for both professional and pedagogical competence

c. Professional competence development very much helped to improve their professional and pedagogical competence

d. EFL teacher's professional competence development has very good and a lot positive effects for their profession as a teacher

e. EFL teacher's professional competence development is really feel indeed greatly help improve their quality in teaching

\section{REFERENCES}

Atmowardoyo, H. 1998a. Model Pembelajar Bahasa Inggris yang Berhasil: Studi Kasus Terhadap Tiga Siswa SMU di Ujung Pandang. Unpublished Dissertation. Jakarta: Post Graduate Programme IKIP Jakarta.

1999b. The Profile of a Successful English Language Learner. Paper

Presentation at English Seminar. Makassar: UNM - 2008c. Metode Penelitian Kualitatif: Teori Dasar. Makassar: Badan Penerbit Universitas Negeri Makassar.

. 2010d. Research Methods For Language And Literature Studies. UNM Makassar: Badan Penerbit UNM.

Anugerahwati, M. 2009. Professional Competence for Teachers of English In ndonesia: A Profile of An Exemplary Teacher. Unpublished Dissertation. School of post Graduate Studies. State university of Malang.

Afsaneh G. at al. 2011. 'The Relationship Between Iranian EFL Teachers' sense of Self-Efficacy and Their Pedagogical Success in Language Institutes" The Asian EFL Journal. Volume 13. Issue 21. (wmw/http. The Asian EFL Journal. Acessed on June 21, 2011)

Asriati, 2013. A Study of Effective English Language Teachers in Makassar. Unpublished Thesis. School of post Graduate Studies. State university of Makassar. 
Bambang, Y.C. 2013. Indonesian EFL Teachers Studying Overseas: Feelings, Expectation, and perspective on professional Competence. A journal of Culture, English Language Teaching and Literature. Celt. Volume 13 no. 1.

Brown, D. H. 2001. Teaching By Principles: An Interactive Approach To Language Pedagogy. New York: A Pearson Education Company.

Departemen Pendidikan Nasional . 2008. Kamus besar Bahasa Indonesia. Edisi IV. Jakarta: PT. Gramedia Pustaka Utama.

Echols, J. M. And Shadily, H. 1992. Kamus Inggris Indonesia. Jakarta: Gramedia.

Fu, A. Q. 2006. Content And Strategy: EFL Teachers' professional Development in China. Hong Kong: APERA Conference.

Gay, L.R., Mills, G.E., \& Airasian, P. 2006. Educational Research Competencies for Analysis and Applications Eight Edition. New Jersey: Pearson Prentice Hall.

Kadha, H. M. 2009. What Makes A Good English Teacher? “Teachers' Perception and Student's Conception. Humanity and Social Sciences Journal. 4 (1): 01-11

Miles, M. B. 1994. An Expanded Coursebook: Qualitative Data Analysis. Second Edition. California: Sage Publication Inc.

Moncada, A. G. 2007. Professional Development of EFL Teachers In Colombia: between Colonial And Local practices. Colombia: Ikala, Revista De Language Y Cultura.

Melvin, L. 2011. How to keep good teachers and principals : practical solutions to today's classroom problems. Maryland: A division of Rowman \& Littlefield Publishers, Inc.

Pettis, J. 1997. Developing Our Professional Competence: Some Reflection. Canada: TESL Canada Journal Vol. 14 No. 2

Rahman, A. W. 2013. Good Lecturer Teaching Performance in Regard to Students' Perception of English Department of Universitas Muhammadiyah Parepare (UMPAR). Unpublished Thesis. School of post Graduate Studies. State university of Makassar.

Richards. J. C. 2011. Competence And Performance In Language Teaching. New York: Cambricge University Press.

Sugiyono. 2009a. Metode Penelitian Pendidikan. Bandung: Alfabeta. 2013b. Metode Penelitian Kuantitatif, Kualitatif dan ReDD. Bandung: Alfabeta. 
Volume 6, Number 1, June 2020

Supyan, H. 2002. Sustaining an Interest in Learning English and Increasing the Motivation to Learn English: An Enrichment Program. Paper_presentation at the Millennium MICELT 2000, $3^{\text {rd }}$ Malaysia International Conference for English Language Teaching. Kuala Lumpur: University Putra Malaysia.

Thompson, S. Highly Qualified for Successful Teaching: Every Teacher Should

Possess. (wwm. Routledge.com/education. Accessed on August 17, 2012.)

Undang-undang Republik Indonesia, No 14 Tahun 2005. Tentang Guru dan Dosen.

(Online), (http://wrks.itb.ac.id/apk-images/files-produk-hukum/uu-142005.pdf, Accessed on 17 March 2013).

Wichadee, S. 2008. Characteristics of Effective Language Teachers: The Perspectives of

Bangkok University Students. Bangkok University Electronic Paper January 2008.

(www.bu.ac.th/knowledgecenter/epaper/jan.../pdf/Page 01.pdf, Accessed on February 19th 2013).

Yuwono, G. I. 2010. English Teacher Professionalism and Development: Some Common Issues In indonesia. The Asian EFL Journal. Volume 12. Issue 3. (www/http. The Asian EFL Journal. Acessed on June 21, 2011)

Yin, R.K. 2011. Qualitative Research from Start to Finish. New York: The Guilford Press. 